Eur. J. Clin. Chem. Clin. Biochem.

Vol. 32, 1994, pp. 681-684

(c) 1994 Walter de Gruyter \& Co. Berlin - New York

\title{
Coagulation Factor XIII in Plasma of Patients with Benign and Malignant Gynaecological Tumours
}

\author{
By J. W. J. van Wersch ${ }^{1}$, C. Peters ${ }^{2}$ and J. M. H. Ubachs ${ }^{2}$ \\ ${ }^{1}$ Department of Haematology \\ 2 Department of Gynaecology \\ De Wever Hospital, Heerlen, The Netherlands
}

(Received April 14/June 20, 1994)

Summary: Fibrinogen and factor XIII were measured in sixty-four women with recently detected gynaecological tumours. Twenty-six of these tumours were benign and 32 were malignant: of the last group, nine patients had metastases. No patient showed clinical signs of bleeding or thrombosis. A reference group consisted of 31 agematched healthy women. For fibrinogen, no significant deviation between the patient groups and the control group was found. The median values of factor XIII were higher in the benign tumour group than in the control group. In patients with a gynaecological tumour and metastases, factor XIII was significantly lower than in the non-metastasized malignancy group or in the benign tumour group.

From a clinical point of view, the determination of the factor XIII activity might be helpful in diagnosing metastases in patients with a gynaecological tumour.

\section{Introduction}

Since an enzymatic assay for plasma factor XIII activity became available, plasma factor XIII concentrations have been measured in various clinical conditions: Crohn's disease (1), colitis ulcerosa (2), systemic haematological disorders (7), morbus HennochSchönlein (3), bacterial infections (3) and several types of neoplastic malignancies $(4,5,6)$. Little is known about the role of factor XIII in cancer (3). Factor XIII has been found in connective tissue stroma (7), where it may cross-link fibrin to the surface of neoplastic cells without decreasing their viability (8), and provide structural integrity and vascularization support to the tumour mass (9). It has been reported that thrombin and factor XIII show mitogenic activity towards some malignant cell types in vitro (10). There are, to our knowledge, no reports on the behaviour of plasmatic factor XIII in gynaecological oncology. Therefore, it was the aim of this study to investigate factor XIII in plasma of patients with benign and malignant gynaecological tumours. Simultaneously the acute phase reactant fibrinogen, was determined to assess whether plasmatic factor XIII may also behave like an acute phase protein.

\section{Materials and Methods}

Patients

Plasma samples were collected from 58 patients with a benign or malignant gynaecological tumour. The diagnosis was later confirmed by histology. On admission to the hospital no patient showed clinical signs of bleeding or thrombosis. Twenty-six patients had a benign disease (tab. 1) and 32 patients a malignancy (tab. 2). In the latter group nine patients had histologically proven metastases, mostly in lymph nodes or peritoneal tissue. The use of medication was excluded. A reference group consisted of 31 agematched subjectively healthy women.

\section{Samples}

The coagulation constituents were determined in citrated plasma prepared by centrifugation of nine volumes of freshly drawn blood with one volume trisodium citrate $(0.11 \mathrm{~mol} / \mathrm{l})$ for $10 \mathrm{~min}(1600 \mathrm{~g})$ at $25^{\circ} \mathrm{C}$. The plasma was stored at $-70^{\circ} \mathrm{C}$ in plastic tubes and thawed with tap water at $37^{\circ} \mathrm{C}$ for $5 \mathrm{~min}$ before serial analysis. 


\section{Methods}

Fibrinogen was determined with a clotting assay (Merz and Dade) according to the method of Clauss, measured by means of a Schnittger and Gross coagulometer. Factor XIII was determined with a photometric assay of Behring Corporation (Marburg, Germany). The Mann-Whitney U test and the $\chi^{2}$-test, where appropriate, were used for statistical analysis.

\section{Results}

In table 1 the basic characteristics of the patients with a benign disease are given. Ovarian cysts occur mostly in this group.

Table 2 shows the various tumour types in the patients with a malignancy. Most of the patients appeared to have a cervix or an ovarian carcinoma. Metastases were especially present in the ovarian carcinoma group.

In table 3 a comparison of the benign tumour group, the total malignant tumour group and an age-matched control group is given. Except for age, the quantities showed a non-Gaussian distribution, and the results are presented as median values and interquartile ranges. The group with a benign gynaecological tumour showed statistically significant, higher median values for factor XIII, compared with the age-matched control group. The median value for factor XIII in the malignant tumour group was not significantly different from that in the age-matched control group.

In table 4 , patients of the malignancy group with and without metastases are compared with the benign tu-

Tab. 1 Basic patient characteristics of the benign tumour group.

\begin{tabular}{ll}
\hline Benign tumour type & Patients \\
\hline Ovarian/adnex cyst & 15 \\
Ovarian fibroma & 3 \\
Ovarian cyst and myoma uteri & 2 \\
Endometrioma & 2 \\
Myoma uteri & 2 \\
Cyst of unknown origin & 2 \\
\hline
\end{tabular}

Tab. 2 Basic patient characteristics of the malignant tumour group.

\begin{tabular}{llll}
\hline $\begin{array}{l}\text { Malignant tumour } \\
\text { type }\end{array}$ & $\begin{array}{l}\text { All } \\
\text { patients }\end{array}$ & $\begin{array}{l}\text { Patients } \\
\text { without } \\
\text { metastases }\end{array}$ & $\begin{array}{l}\text { Patients } \\
\text { with } \\
\text { metastases }\end{array}$ \\
\hline Carcinoma cervicis & 12 & 11 & 1 \\
Ovarian carcinoma & 10 & 3 & 7 \\
Endometrium carcinoma & 6 & 6 & 0 \\
Carcinoma of vulva & 2 & 2 & 0 \\
Leiomyosarcoma uteri & 1 & 1 & 0 \\
Sarcoma uteri & 1 & 0 & 1 \\
\hline
\end{tabular}

mour group. A significant decrease of factor XIII values was seen in the group with metastases.

Table 5 gives the percentages of decreased and increased values of fibrinogen and factor XIII in the three patient groups, based on the laboratary reference ranges. The values of fibrinogen did not show a statistically significant difference.

A significant proportion of the factor XIII values were decreased in the metastasis group, compared with the other two patient groups.

\section{Discussion}

No significant differences were found in the fibrinogen levels of patients with a benign or malignant gynaecological tumour, nor in any of these groups compared with the control group.

Factor XIII values in patients with a benign gynaecological tumour and in patients with a non-metastasized malignant tumour, however, were significantly enhanced in comparison with the control group. An explanation for this phenomenon might be that additional tissue factor XIII is released from these tumours. This possibility is strengthened by a recent review by Aeschliman \& Paulsson (11), on the localization and function of factor XIII, in which it is shown that tissue factor XIII is nearly ubiquitous. Factor XIII values were significantly decreased in patients with metastases compared with the patients without metastases and the patients with benign tumours. This finding might be relevant, since factor XIII is important for the cross-linking of proteins other than fibrin. Lowered factor XIII concentrations have been reported in malignant melanoma, breast cancer and gastric cancer $(4,5,12)$, but decreased factor XIII has not been found in patients with lung cancer or colonic cancer $(13,14)$.

An explanation for the decrease might be the consumption of factor XIII during the cross-linking of proteins in and around the tumour. Consumption during local activation of the clotting system promotes tumour maintenance and perpetuation by conversion of fibrinogen to fibrin (9). Moreover, factor XIII is used for the crosslinking of fibrin and $\alpha_{2}$-antiplasmin to the surface of neoplastic cells $(7,8)$, which promotes tumour growth and prevents fibrinolytic degradation. The presence of thrombin and factor XIII on the tumour site may therefore contribute to tumour progression (10). In an earlier study it was established that patients with a metastasized gynaecological tumour displayed high levels of coagulation activation and reactive fibrinolysis. Therefore, reduced plasma factor XIII concentrations may at least 
Tab. 3 Comparison of the benign and total malignant tumour groups with an age-matched control group.

\begin{tabular}{|c|c|c|c|c|c|c|}
\hline & \multirow{2}{*}{$\begin{array}{l}\text { Patients with benign } \\
\text { gynaecological tumour } \\
\text { (G1) }\end{array}$} & \multirow{2}{*}{$\begin{array}{l}\text { Total patient group } \\
\text { with malignant } \\
\text { gynaecological tumour } \\
\text { (G2) }\end{array}$} & \multirow{2}{*}{$\begin{array}{l}\text { Age matched } \\
\text { control group }\end{array}$} & \multicolumn{3}{|c|}{ Significance/p-value } \\
\hline & & & & G1 vs $\mathrm{G} 2$ & G1 vs $\mathrm{G} 3$ & G2 vs G3 \\
\hline & $\begin{array}{l}\text { Median } \\
\text { ( } 25-75 \text { percentiles) }\end{array}$ & $\begin{array}{l}\text { Median } \\
\text { (25-75 percentiles) }\end{array}$ & $\begin{array}{l}\text { Median } \\
\text { ( } 25-75 \text { percentiles) }\end{array}$ & & & \\
\hline & Number 26 & Number 32 & Number 31 & & & \\
\hline Age & $\begin{array}{l}53 \\
(45-65)\end{array}$ & $\begin{array}{l}57 \\
(48-68)\end{array}$ & $\begin{array}{l}51 \\
(49-54)\end{array}$ & n.s. & n.s. & n.s. \\
\hline Fibrinogen $(\mathrm{g} / \mathrm{l})$ & $\begin{array}{l}3.6 \\
(2.9-4.6)\end{array}$ & $\begin{array}{l}3.6 \\
(3.2-4.0)\end{array}$ & $\begin{array}{l}3.6 \\
(3.3-4.2)\end{array}$ & n.s. & n.s. & n.s. \\
\hline Factor XIII (\%) & $\begin{array}{l}124 \\
(106-146)\end{array}$ & $\begin{array}{l}118 \\
(93-131)\end{array}$ & $\begin{array}{l}107 \\
(94-129)\end{array}$ & n.s. & 0.002 & n.s. \\
\hline
\end{tabular}

Tab. 4 Comparison of the malignant tumour groups with and without metastases and the benign tumour group.

\begin{tabular}{|c|c|c|c|c|c|c|}
\hline & \multirow{2}{*}{$\begin{array}{l}\text { Patients with benign } \\
\text { gynaecological } \\
\text { tumour }\end{array}$} & \multirow{2}{*}{$\begin{array}{l}\text { Patients with } \\
\text { malignant } \\
\text { gynaecological tumour } \\
\text { without metastases } \\
\text { (G2) }\end{array}$} & \multirow{2}{*}{$\begin{array}{l}\text { Patients with } \\
\text { malignant } \\
\text { gynaecological tumour } \\
\text { and metastases } \\
\text { (G3) }\end{array}$} & \multicolumn{3}{|c|}{ Significance/p-value } \\
\hline & & & & $\mathrm{G} 1$ vs $\mathrm{G} 2$ & G1 vs $G 3$ & G2 vs $G 3$ \\
\hline & $\begin{array}{l}\text { Median } \\
\text { (25-75 percentiles) }\end{array}$ & $\begin{array}{l}\text { Median } \\
\text { ( } 25-75 \text { percentiles) }\end{array}$ & $\begin{array}{l}\text { Median } \\
\text { (25-75 percentiles) }\end{array}$ & & & \\
\hline & Number 26 & Number 23 & Number 9 & & & \\
\hline Age & $\begin{array}{l}53 \\
(45-65)\end{array}$ & $\begin{array}{l}60 \\
(45-70)\end{array}$ & $\begin{array}{l}54 \\
(49-65)\end{array}$ & n.s. & n.s. & n.s. \\
\hline Fibrinogen $(\mathrm{g} / \mathrm{l})$ & $\begin{array}{l}3.6 \\
(2.9-4.6)\end{array}$ & $\begin{array}{l}3.5 \\
(3.1-4.0)\end{array}$ & $\begin{array}{l}3.7 \\
(3.2-4.4)\end{array}$ & n.s. & n.s. & n.s. \\
\hline Factor XIII (\%) & $\begin{array}{l}124 \\
(106-146)\end{array}$ & $\begin{array}{l}124 \\
(110-134)\end{array}$ & $\begin{array}{l}79 \\
(58-93)\end{array}$ & n.s. & $<0.001$ & 0.001 \\
\hline
\end{tabular}

Tab. 5 Percentage of decreased and increased values of various coagulation and fibrinolysis constituents based on laboratory reference ranges.
The significant values are indicated $\left(\chi^{2}\right.$-test): $\left.\left.{ }^{1}\right) \mathrm{p}=0.005 ;{ }^{2}\right) \mathrm{p}=$ $0.005 ;^{3}$ ) $p=0.0006$

\begin{tabular}{|c|c|c|c|c|c|c|c|c|}
\hline & \multirow[t]{2}{*}{. } & \multicolumn{2}{|c|}{$\begin{array}{l}\text { Patients with benign } \\
\text { gynaecological tumour } \\
\text { (G1) }\end{array}$} & \multicolumn{2}{|c|}{$\begin{array}{l}\text { Patients with malignant } \\
\text { gynaecological tumour } \\
\text { without metastases } \\
\text { (G1) }\end{array}$} & \multicolumn{2}{|c|}{$\begin{array}{l}\text { Patients with malignant } \\
\text { gynaecological tumour } \\
\text { and metastases } \\
\text { (G2) }\end{array}$} & \multirow[t]{2}{*}{$\begin{array}{l}\text { Laboratory } \\
\text { reference } \\
\text { range }\end{array}$} \\
\hline & & $\begin{array}{l}\text { Decreased } \\
\text { values } \\
(\%)\end{array}$ & $\begin{array}{l}\text { Increased } \\
\text { values } \\
(\%)\end{array}$ & $\begin{array}{l}\text { Decreased } \\
\text { values } \\
(\%)\end{array}$ & $\begin{array}{l}\text { Increased } \\
\text { values } \\
(\%)\end{array}$ & $\begin{array}{l}\text { Decreased } \\
\text { values } \\
(\%)\end{array}$ & $\begin{array}{l}\text { Increased } \\
\text { values } \\
(\%)\end{array}$ & \\
\hline $\begin{array}{l}\text { Fibrinogen } \\
\text { Factor XIII }\end{array}$ & $\begin{array}{l}(\mathrm{g} / 1) \\
(\%)\end{array}$ & $\begin{array}{l}0 \\
0\end{array}$ & $\begin{array}{l}19.6 \\
\left.18.5^{2}\right)\end{array}$ & $\begin{array}{l}0 \\
\left.0^{3}\right)\end{array}$ & $\begin{array}{l}17.4 \\
\left.17.4^{1}\right)\end{array}$ & $\begin{array}{c}0 \\
\left.44.4^{3}\right)\end{array}$ & $\begin{array}{c}33.3 \\
\left.\left.0^{1}\right)^{2}\right)\end{array}$ & $\begin{array}{l}1.7-4.0 \\
67-147\end{array}$ \\
\hline
\end{tabular}

partly be due to enhanced consumption for cross-linking purposes. In addition, the factor XIII reduction may be the result of enhanced unspecific proteolysis by e.g. neutrophil elastase. Low activities of factor XIII have been reported in other diseases with increased elastase- $\alpha_{1}$-antitrypsin complexes $(15,16,17)$. An enhanced proteolyis of factor XIII in patients with metastases is possible, since an elevation of the proteolytic activity has also been reported in tumour patients. 
In conclusion, factor XIII and fibrinogen did not behave synchronously in the different gynaecological tumour groups. This finding does not support the idea that factor XIII might possess acute phase charactertistics. For the

\section{References}

1. Wisen, O. \& Gårlund, B. (1988) Hemostasis in Crohn's disease: Low factor XIII levels in active disease. Scand. J. Gastroenterol. 23, 961-966.

2. Suzuki, R., Toda, H. \& Takamura, Y. (1989) Dynamics of blood coagulation factor XIII in ulcerative colitis and preliminary study of the factor XIII concentrate. Blut 59, 162-164.

3. Egbring, R., Keiling, A., Kehl, H. G., Seitz, R., Wallin, R. \& Saldeen, T. (1990) Factor XIII deficiency in inflammatory bowel disease, systemic haematological disorders, Morbus Schönlein Hennoch (MSH) and bacterial infections. Treatment of bleeding complications by factor XIII concentrates. Blut 60 , 121 (abstract).

4. Wojtukiewicz, M. Z., Zacharski, L. R., Memoli, V. A., Kisiel, W., Kudryk, B. J., Rousseau, S. M. \& Stump, D. C. (1990) Abnormal regulation of coagulation/fibrinolysis in small cell carcinoma of the lung. Cancer 65, 481-485.

5. Wojtukiewicz, M. Z., Zacharski, L. R., Memoli, V. A., Kisiel, W., Kudryk, B. J., Rousseau, S. M. \& Stump, D. C. (1990) Malignant melanoma: Interaction with coagulation and fibrinolysis in situ. Am. J. Clin. Pathol. 93, 516-521.

6. Wojtukiewicz, M. Z., Zacharski, L. R., Memoli, V. A., Kisiel, W., Kudryk, B. J., Rousseau, S. M. \& Stump, D. C. (1989) Indirect activation of blood coagulation in colon cancer. Thromb. Haemostas. 62, 1062-1066.

7. Zacharski, L. R., Memoli, V. A., Rousseau, S. M. \& Kisiel, W. (1987) Coagulation-cancer interaction in situ in small cell carcinoma of the lung. Cancer 60, 2675-2681.

8. Fesus, L. \& Laki, K. (1976) On coupling bovine fibrinogen to the surface of malignant murine plasma cells by means of transglutaminase. Biochem. Biophys. Res. Comm. 72, 131137.

9. Dvorak, H. F., Harvey, V. S., Estrella, P., Brown, L. F., McDonagh, J. \& Dvorak, A. M. (1987) Fibrin containing gels induce angiogenesis. Implications for tumor stroma generation and wound healing. Lab. Invest. 57, 673-686. clinician, however, the determination of factor XIII may provide an aid to the diagnosis of metastasis in patients with gynaecological tumours.

10. Bruhn, H. D., Bernsmeier, R., Luck, P., Zurborn, K. H. \& Christophers, E. (19.83) Influences of thrombin, factor XIII and fibronectin on the growth of tumor cells and leukemic cells in vitro. Klin. Wochenschr. 61, 209-211.

11. Aeschlimann, D. \& Paulsson, M. (1994) Transglutaminases: Protein cross-linking enzymes in tissues and body fluids. Thromb. Haemostas. 71, 402-415.

12. Wojtukiewicz, M. Z., Koczko, J., Bielawiec, M. \& Galar, M. (1993) Heterogeneity of factor XIII plasmatic substrate concentrations in different tumour types. In: $F$ XIII (McDonagh, J., R. Seitz \& Egbring, R., eds.) Schattauer Verlag, pp. 205209, ISBN 3-7945-1543-9.

13. Wersch van, J. W. J. \& Tjwa, M. K. T. (1991) The coagulation fibrinolysis balance and lung cancer. Haemostasis $21,117-$ 123.

14. Duijnhoven van, E. M., Lustermans, F. A. T. \& van Wersch, J. W. J. (1993) Evaluation of the coagulation/fibrinolysis balance in patients with colorectal cancer. Haemostasis 23, $168-172$.

15. Seitz, R., Kehnen, B., Küsters, G. \& Egbring, R. (1993) Pathogenic causes of acquired factor XIII deficiency. In: F XIII (McDonagh, J., Seitz, R. \& Egbring, R., eds.) Schattauer Verlag, pp. 172-175, ISBN 3-7945-1543-9.

16. Hergesell, O., Andrassy, K., Egbring, R., Schaefer, A. \& Seitz, R. (1993) F XIII elastase- $\alpha_{1}$-antitrypsin complexes and activation of coagulation in patients with systemic necrotizing vasculitis. In: F XIII (McDonagh, J., Seitz, R. \& Egbring, R., eds.) Schattauer Verlag, pp. 193-200, ISBN 3-7945-1543-9.

17. Egbring, R., Schmidt, W., Fuchs, G. \& Havemann, K. (1977) Demonstration of granulocytic proteases in plasma of patients with acute leukemia and septicemia with coagulation defects. Blood 49, 219-231.

Dr. J. W. J. van Wersch

De Wever Hospital

P. O. Box 4446

NL-6401 CX Heerlen

The Netherlands 